\title{
EDITORIAL
}

nature

cell biology

\section{Attracting women}

\section{Women remain underrepresented in senior academic positions, despite similar numbers of male and female graduates. The imbalance is best addressed by focusing on the reasons for divergent career choices.}

Most knowledge-based economies project deficits in the highly trained workforce. A strong academic culture is at the heart of such economies, and those that attract the best minds will have a competitive advantage. The US has done particularly well to populate its research institutions with foreign scientists, but, like other countries, it is still losing out on a good proportion of its indigenous talent, both in terms of women and non-white researchers. Reversing this brain drain is essential, not only to achieve gender and racial equality, but to bolster productivity, as better researchers should emerge from a bigger pool and, arguably, a genderbalanced faculty might encourage a more collaborative research culture (Nature Cell Biol. 8, 899; 2006).

In the biological sciences, women now account for about half of graduates and postgraduates in North America, many Asian countries and Europe. How is it then that in the US they represent only $19 \%$ of tenured NIH staff and $25 \%$ of NIH grant recipients? The percentage of tenured female academics and grant recipients is even lower in many European countries, as analysed in two new European Commission (EC) reports. Japan is still prone to some level of discrimination, or at least an expectation to conform to a more traditional division between family and work. In Germany, infrastructure, such as childcare and shop opening times, is still often suboptimal for working families, which tends to disadvantage women. However, in other countries, particularly the US, underrepresentation of women in senior positions persists even though these hurdles are less evident. Indeed, any vestiges of chauvinism would be compensated by affirmative action. There is more than anecdotal evidence for this: a new report by the US National Academies based on surveys in 2004-2005 of 1,800 faculty members at 89 top-tier institutions concluded, in contrast to previous reports, that "gender does not appear to have been a factor in a number of important career transitions". Indeed, women were more likely to have been interviewed for tenure-track positions ( $2 \%$ more than their application rate), to obtain an offer (10\% higher than application rate) and as likely to achieve tenure. However, fewer women applied for tenure-track positions in the first place (26\%, whereas $45 \%$ of $\mathrm{PhDs}$ are female) and women remained as assistant professors for longer and with a higher attrition rate, compared with men. The report confirmed a significant salary differential, but rightly notes that this might be attributed to differences in seniority. Claude Canizares, co-author of the report, commented that "while women can take some encouragement from the fact that there is no evidence for large scale bias..., the reason for their continued underrepresentation needs to be examined." He agrees that more longitudinal studies are necessary: "We studied the women who make it, we don't know anything about the ones who left".

What are the forces at work that cause the lamentable imbalance to persist? One explanation is simply that many of the gender equality changes are recent-after all, it takes a decade for graduates to advance to senior academic appointments. We can expect the rate of female senior faculty appointments to increase as more women in such positions serve as role models. Indeed, the National Academies report found that female representation on selection committees attracted a higher proportion of woman applicants.

Nevertheless, numbers are rising so slowly that there must be other reasons for women to forego a career in academia. A key factor is children: even with childcare, women obviously have to take time out for children. We commented previously on the importance of a flexible tenure clock and part-time work (Nature Cell Biol. 9, 1101), but these provisions must also be taken into account by grant agencies. However taking extended time out will always be a disadvantage in a competitive research environment, as papers, the key measure of productivity, can be delayed or scooped. Until attributes like mentoring, collaborations and innovation are also considered, those compromising their publication output will always tend to lose out. On the other hand, the short period of parental leave common in the US will discourage those who favour a more proactive role in their children's first years. Although parental leave is longer in Europe, few countries have addressed a key discrepancy favouring the male career: men get far less parental leave. Even if both sexes get the same amount of parental leave, given societal norms, the playing field will only ever be levelled if there is active encouragement for men to take a similar amount of time off. In fact international norms on parental leave would best serve to give women the same chances in the global research enterprise.

A 2007 survey of more than 1,300 NIH postdoctoral fellows $(43 \%$ female) commissioned by the NIH showed that women with children were already underrepresented at the postdoctoral level (10\% fewer than men with children, same age distribution). Women were less likely to consider a Principal Investigator position (51\% compared with $70 \%$ men), especially those with children ( $45 \%$ compared with $69 \%$ men with children), and they were more prone to consider family responsibilities as a source of conflict with professional life. Moreover, women were more ready to make career concessions for their partners. Women seem to have less self-confidence, as they were $20 \%$ less likely to persevere after a failed first attempt to secure a Principal Investigator position, which 19\% more men were confident they would eventually obtain. Men seemed better at securing technical support and a transferrable project, and the salary differential might also relate to better negotiation skills. On the other hand, we found no evidence that male authors had more papers published in NCB (Nature Cell Biol. 8, 899; 2006). Also, two recent large bibliometric studies concluded that gender had no effect on peer review (see Nature 459, 602; 2009).

No country can afford to be complacent in pursuing gender and racial equality in academia and, as more subtle reasons for divergent career choices emerge, governments and funding agencies must have an active role in addressing them. Indeed, both the NIH and EC reports concluded that women were far more likely to find Principal Investigator positions with affordable childcare and flexible working arrangements attractive. Encouraging smaller labs would also serve to attract female Principal Investigators. Affirmative action yields neither equality nor quality. Crucially, "stating a family shouldn't be seen as a weakness", as Sally Shaywitz, co-author of the NAS study puts it. According to the Association for Women in Science, most female $\mathrm{PhDs}$ who leave academia take on alternative jobs, indicating that an academic career is currently simply less attractive for them.

Further reading: www.connotea.org/user/bpulverer/tag/women\%20science 